\title{
Connecting Teachers: A Virtual Environment for Networking and Innovation
}

\author{
Marisol Esperanza Cipagauta ${ }^{1}$, Yendy Viviana Castellanos ${ }^{2, *}$ Mónica Alejandra Bautista ${ }^{3}$ \\ ${ }^{1}$ Director at the Center for Teaching Excellence at Corporación Universitaria Minuto de \\ Dios, Colombia \\ ${ }^{2}$ Manager of learning environments at the Center for Teaching Excellence at Corporación \\ Universitaria Minuto de Dios, Colombi (Corresponding author) \\ ${ }^{3}$ Manager at the Center for Teaching Excellence at Corporación Universitaria Minuto de \\ Dios, Colombia.
}

\section{ARTICLE INFO \\ Keywords: \\ Higher Education, ICT, \\ Innovative Pedagogical \\ Practices, Institutional \\ Strategies.}

\begin{abstract}
Educational innovation and collaborative work among teachers are some of the most critical challenges that higher education institutions currently have, especially when the geographical locations of the university's headquarters are in different places. UNIMINUTO is a university with more than 4700 teachers, present in 64 different locations in Colombia, making the training processes and meetings for teachers a challenging task. The current paper shows the results, and perceived benefits of the Fourth Annual Meeting of Innovative Pedagogical Practices, an online space conceived as an institutional strategy to acknowledge and share innovative experiences inside different learning environments, created by our teachers. The meeting took place through UNIMINUTO YouTube Streaming channel, with the primary goal of increasing access and participation of teachers inside the organization. However, the results showed that even people from other educational organizations and cities interacted in the meeting, increasing the visibility of the teachers and their practices, allowing them to receive feedback from different sources and to create new networks. At the same time, teachers perceived this online strategy as a way to make knowledge available to them, more accessible in terms of times and costs because they could access it without investing in any transportation costs. Those results open the path to transforming those classroom experiences into collaborative educational research, adding value to the institutional strategy towards improving learning outcomes by using didactics that help future professionals develop their skills and competences through didactics and innovation.
\end{abstract}

\section{Introduction}

Educational innovation is one of the main concerns for Higher Education Institutions, mainly because it relates to the increment of education and teachers' quality (Ellis, 2017; Kovacs, 2019),

\footnotetext{
$\square$ Corresponding Author E-Mail Address: monica.bautista@uniminuto.edu
} 
and the maintenance of currency and pertinence in educational programs (Hrabowski, 2014). It is linked to better learning outcomes and competencies acquisition in students (Beames, 2017; Liu, 2018; Hrabowski, 2014) and as a critical process to bring together the academic world with communities and real needs (Taylor et al., 2015).

Innovation in higher education is often understood as the exercise of creating new products and patents derived from research projects. However, sometimes, teachers are not prepared to lead this kind of initiative mainly because they do not have the proper preparation for pedagogical strategies towards innovation as well (Jakovljevic, 2019). It is then when is where active learning strategies and innovative pedagogical practices gain significant importance in aiding students to acquire competencies requested in the working environment (Liu, 2018; Lawrence et al., 2019; MayoloDeloisa et al., 2019) being innovation one of them. However, it also sets the need for institutional policies and teachers' training processes that allow them to transform the learning environments and learning processes (Rees et al., 2019; Kovacs, 2019).

\subsection{Hidden educational innovation and crucial elements to achieve it}

In the educational context, teachers usually create new ways and methods to improve their teaching and their students' learning outcomes. Still those practices often remain hidden to others who could validate and adopt those practices increasing the impact of those, and the main reason for that relies on the fact that the teacher does not acknowledge their job or does not even know what their co-workers do. Innovation requires diffusion and collaboration and networking to stand out and have a real impact (Warford, 2017; Ellis, 2017), but it is impossible to get there if the members of the academic community do not know what their peers do.

Some research say teachers do not innovate due to resistances such as the use of technologies in higher education (Watty, et. al., 2016), while other identify that, in order to innovate in education, educational institutions must create an "organizational culture and structures in line with the new adaptative ways of working" (Kunnari \& Ilomäki, 2016, p. 168), in order to support their efforts.

\subsection{Collaborative work between teachers}

In this process, however, a crucial element is the collaboration among teachers (Kunnari \& Ilomäki, 2016) and the integration of the academic community towards educational innovation (Hrabowski, 2014), mainly because it is collaboration, recognition, and diffusion what makes innovation effective. Authors such as Rogers (2003, in Kunnari \& Ilomäki, 2016) establish that it is through networking and sharing that educational innovations are known enough to generate and educational change, mainly because teachers receive support from their colleagues and other members of the community; that at the same time creates the feeling of appreciation of the work (Messmann \& Mulder, 2011; in Kunnari \& Ilomäki, 2016).

Authors such as Ching \& Hursh (2014), Kunnari \& Ilomäki (2016), identified that creating communities of practices, fostering collaboration, communication and networking among teachers and other members of the academic community, is the best way to ensure efficiency in academic processes (Loera et. al., 2013) like innovation and research in the educational environment. That will help innovative strategies to be a continuous procedure instead of an isolated effort of a teacher trying to influence a limited amount of students, which is why UNIMINUTO has created a unit to accompany teachers, and an event to help them networking towards educational innovation and new practices. 


\subsection{Context}

UNIMINUTO is currently the largest University in Colombia, with more than 50 branches with an academic offer in the country, more than 106.000 students, and 4.702 teachers. Its primary mission is to offer high-quality education for everyone, with a preferential option for those who cannot access Higher Education in other universities (Corporación Universitaria Minuto de Dios, 2017). This scenery creates a challenge to achieve collaborative work among teachers from different places of the university, primarily related to didactic innovation and new ways of teaching to obtain better learning outcomes, so the pedagogical exercises and creations of the teachers remained as individual efforts towards the achievement of educational goals, but were not within an institutional strategy.

In 2016, The General Vice rectory of the University created the Center for Teaching Excellence aeiou, as a unit to accompany teachers and provide training towards the improvement of pedagogical practices in the learning environments and educational innovation, launched in the first annual meeting for Innovative Pedagogical Practices.

The meeting emerged as a scenery where teachers could share their innovative practices and acknowledge their partners', the Annual Meeting for Innovative Pedagogical Practices is an open call event where teachers send their texts for evaluation by experts, who evaluate the pedagogical goal, pedagogical strategies, and obtained results.

The first meeting took place in Bogotá, allowing the participation of teachers from Bogotá and its surroundings, leaving teachers from other regions apart. The second event pretended to gather teachers from different regions of the country, counting with the participation of 300 teachers from 21 branches of the university, with a substantial charge for the budget due to the transportation and lodging expenses, space rental for the event and other logistics costs.

The third event wanted to start with the democratization of the event, so it took place in four different branches of the university, where teachers from surrounding places could arrive. The leading conferences were transmitted online to the other sites where teachers gathered; however, teachers' innovative proposals were exposed in specific places, which did not allow the entire community to know their colleagues' whole works. In the end, even though the results were good, did not allow teachers to create new networks and collaboration possibilities, and the access to the event required from teachers to invest time and money to get to the event, impacting the second day of the meeting due to a decline in participation.

Research about innovative strategies and didactic trends has been made these last years (Cipagauta \& Bautista, 2019), as well as new efforts and on-line spaces, are being created and encouraged to promote networking and collaborative work among teachers (Castellanos \& Cipagauta, 2019). Still, no formal analysis has been made in the event itself to determine its efficacy and impact, however as the previous versions of the meeting led the Center to identify some logistic and procedural issues such as costs, time management during the event, and mainly a sort of lack in participation and networking, the meeting was redesigned in 2019.

\subsubsection{The meeting strategy for 2019}

The strategy for 2019 aimed mainly to increase the participation of teachers from different places at the same time, especially of those who were not in a big city, so the networking exercise and the acknowledgment of pedagogical practices counted with different points of view and 
diverse perspectives. Therefore, the best way to give access to everyone who could be interested in the meeting was the YouTube streaming option, from UNIMINUTO's official channel, because people could access it without an invitation link and did not require the installation of any platform, which facilitate technological access for people.

To ensure the quality of the transmission, presentations were recorded on a video and sent to the Center for Teaching Excellence for compilation and technical adjustments. Every video had a maximum duration of 5 minutes, based on a pitch methodology where the most important elements to show the innovative practice were:

- The academic program, course, and city where the practice was developed.

- The pedagogical objective of the innovative practice based on the question: "What do I want students to achieve after the innovative practice?

- Didactic strategy and the step by step of the strategy showing the critical processes for the innovative practice.

- Results based on the pedagogical strategy achievement and other benefits resulting from the practice.

The main goals pursued with the pitch were to incentive teachers to present their projects differently, focused on "selling the idea" to their partner, transforming the typical environment of academic presentations; while generating interest from their peers to work together and contact the speakers if they wanted to have more information.

The impact of the event was going to be evaluated in terms of access and coverage, to determine if this was a more effective way to bring teachers and regions together; and in terms of general perception, appraised from the analysis of the comments around the meeting, and the practices presented. The methodology for the analysis is described below.

\section{Methods}

\subsection{Design and scope}

The " 4 th Meeting for Educational Innovative Pedagogical Practices" was the first event of its kind held online in the Center for Teaching Excellence. Therefore, it was necessary to assess the perceived benefits and impacts it had generated, therefore, it uses a mixed methodology with a triangulation design and an exploratory scope; mainly because it allows gathering, comparing, and confirming both qualitative and quantitative information in order to deepen on the analysis (Hernández- Sampieri, fernández, \& Baptista, 2014).

\subsection{Categories, stages of analysis, and instruments}

The initial categories were created arbitrarily, taking into account the main goals that the realization of the online event had, in comparison to the previous meeting. Those were:

- Access and coverage: Meant to evaluate the perception of Access and Coverage of the event itself. 
- Networking: Related to the possibilities perceived by teachers to interact with their partners, acknowledge their work, and generate collaboration possibilities.

- Regional participation: Understood as the presence and participation of teachers from small cities and towns, who usually do not participate in national academic events.

- Logistics: This category gathered all the opinions related to time- management, transportation-related opinions, and all those elements related to the logistic preparation of the event.

There were two different sources of information to analyze: 1) The comments in the live transmission related to the variables of interest and, 2) an online survey with numeric score from one to five, being one the lowest possible grading; and a second part with open questions to perform a speech content analysis that could create emerging categories for the analysis.

The online survey had three main parts

1) Characterization data (academic program, teaching modality of the program, city, and headquarter he/ she works for; no name, gender, or age were asked).

2) Quantitative grading of the event: where they had to assess from 1 to 5 the following elements.

- $\quad$ Time management (Logistics)

- Streaming Quality (Logistics)

- The innovation degree of the Practices presented in the meeting (Networking/ Peer acknowledgment)

- Interaction possibilities during the meeting (Networking/ Interaction)

- Regional participation

3) Open questions

- What did you like the most of the event and why?

- What advantages had the realization of the event online?

- What could improve for the next version of the meeting?

Through the analysis of this instrument and of the comments during the live streaming, the number of views of the event on YouTube, the following results were extracted.

\subsection{Sample and sampling method}

The sample for both analyses was voluntary because the comments and the answers to the survey were not mandatory and mainly depended upon the willingness of participants of the event. 
In the end, the survey had a total of 77 answers, and the comments analyzed from the live event, after the first filter, were 161.

\section{Results}

This section has two subsections, the first one will show some statistics about the participation in the event, and the second focuses on the analysis of the live comments during the event, followed by the survey and open questions analysis. This last part is presented based on the main categories found during the research process.

\subsection{Characterization and statistics of the event}

\subsubsection{Participants, attendants, and speakers}

The number of registrations to attend the event before its emission was 388 people, and during the event, the number of live connected people varied from 30 to 80 people during the day. However, when checking the number of views on YouTube (available in https://youtu.be/3tTt9ccNnQ) for the first day are 1331, and for the second day (available in https://youtu.be/6wzWA_GrAIg) are 502 by November 14, 2019.

The cities from where teachers participated as viewers in the event were identified by reviewing the live chat to determine the places they claimed to be, identifying 25 branches of the university in 22 cities and other 2 administrative units of the university were present during the event, increasing the coverage by more than $200 \%$ taking into account the data from 2018 ( 7 university branches participating in 4 cities).

However, the participation of people from Chile, Costa Rica, Spain, Italy, Mexico, Peru, and Venezuela took place during the meeting, as well as the connection of educational institutions from outside UNIMINUTO, such as Uniclaretiana in Colombia, and institutions from other levels of education. Those results exceeded the expectations for coverage and access, but this will be explained further with the qualitative analysis.

As for the meeting call, a total of 82 Innovative Pedagogical Practices were presented for evaluation, from 22 branches of the University, representing each main headquarter (12 in the country). From those 82, 33 were selected to present on the meeting, taking into account the evaluation score, representing 10 of those 12 branches. Teachers acknowledged and approached their co-workers' experiences in other places of the country, which allowed the recognition of their activities and the interaction among them. That will be explored more profoundly in the qualitative analysis.

\subsection{Analysis of live event comments, survey, and open questions}

When performing the speech analysis for the live comments and the open questions in the survey, the categories proposed initially were transformed due to the emergence of others, resulting in the following structure (see figure 1).

The category Democratization of Knowledge refers to "...eliminating barriers and granting access so that new ideas can spread." (Coleman, 2012; in Inefuku, 2017, par. 2), which was one of the main objectives in 2019, therefore being the most important term and the main one to understand the impacts associated with the compounding elements within the category. Networking gathers all those impressions related to sharing, interaction, and collaboration, as well 
as the teachers' acknowledgment of their co-workers' proposals. The participation of students emerged during the event because they attended and commented on their teachers' presentations, which is why all their interventions were gathered in "students' acknowledgment" category.

The third category was related to comments on flexibility, understood as the possibility attendants had to participate in the meeting while performing other activities, for example, different to logistics, which gather the comments related to elements such as time management and displacements. The last category was named "likes" and gathered positive comments regarding the event that did not match any of the other available categories.

Figure 1. Categories and subcategories final structure

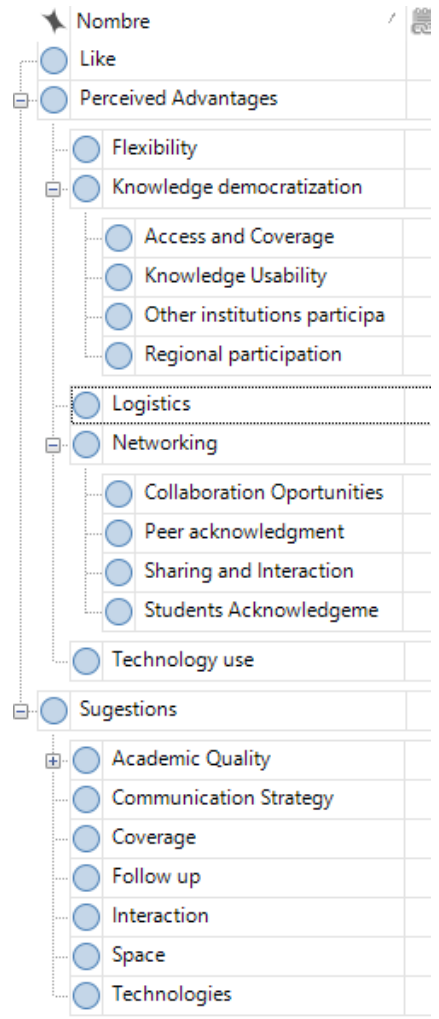

Source: N Vivo

The codification exercise shows that most live comments in the event classify in "Democratization of Knowledge" and "Networking" (see figure 2). 
Figure 2. Hierarchy map of nodes for live comments

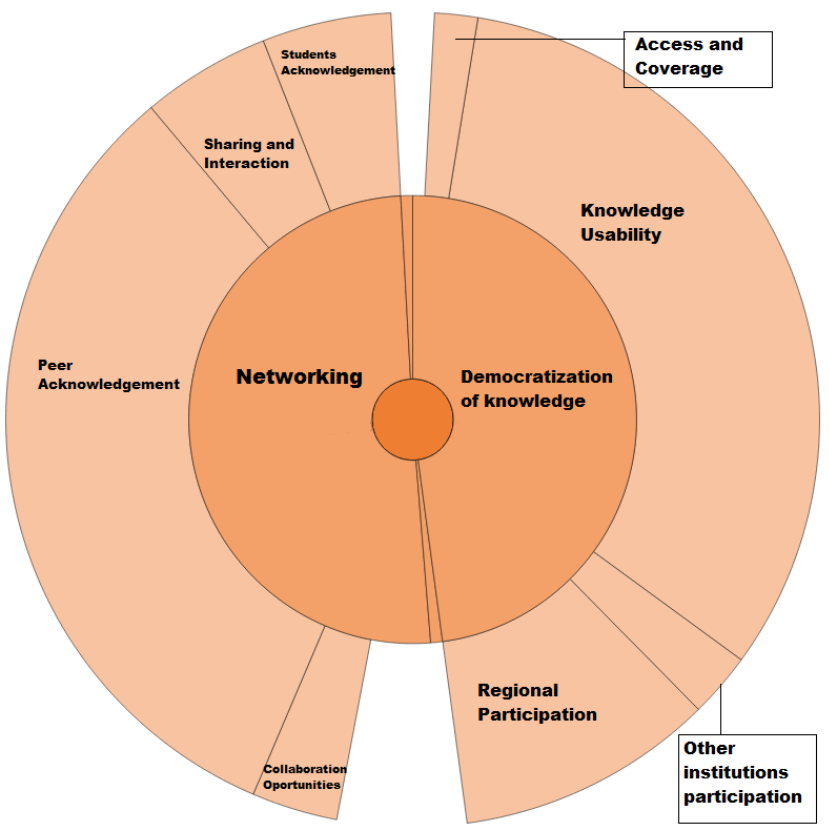

Source. NVIVO

The open question analysis also showed that the most important categories were also Networking and Knowledge Democratization. However, this time Logistics and Technology use appeared with more strength in their perception of the questions $;$ What did you like most of the event and why? And, what advantages had the realization of the event online?

Therefore, the following results will show first the finding regarding the Networking category, following with Democratization of Knowledge and closing with other categories.

\subsection{Networking}

\subsubsection{Networking results from live event comments}

The main results from the analysis show that teachers perceived the event as a place to acknowledge their peers and proposals along the country, not only concerning the teaching activity but as a way to contribute to communities development where the university is present, as well as to develop the academic community itself.

"Son significativas las experiencias que cada docente se esmera en construir en pro de la construcción de situaciones significativas para nuestros entidades y los territorios donde estamos presentes [The experiences that each teacher strives to build for the construction of situations for our entities and the territories where we are, are meaningful]" (Participant Puerto G.). 
"Buenas tardes desde Buenaventura, Feliz de ver las diferentes estrategias que nuestros docentes y estudiantes han implementado para poder llevar el conocimiento a la comunidad en general. [Good afternoon from Buenaventura. I'm happy to see the different strategies that our teachers and students have implemented to bring knowledge to the community in general]" (Participant Ardila, M.).

"Felicito a UNIMINUTO por este evento académico el cual nos comparte saberes innovadores en pro de aportar a la transformación social!! [I congratulate UNIMINUTO for this academic event that shares innovative knowledge to contribute to social transformation]" (Participant Samboní).

"Excelente trabajo del equipo de aeiou, conectando a los profesores del sistema UNIMINUTO con espacios para el desarrollo de la comunidad educativa [Excellent job from the aeiou team, connecting teachers from UNIMINUTO with spaces to develop the academic community]" (Participant Manrique, J.).

Some teachers saw in their colleagues' job opportunities to improve their pedagogical practice and teaching strategies and as exciting schemes to adopt in their own practice.

"Estas propuestas son muy interesantes como estrategias para aplicar en nuestras aulas. [These proposals are very interesting as strategies to apply in our classrooms]" (Participant Gómez, F.)

"Este tipo de experiencias son un trampolín, promueve nuevas iniciativas. Gracias a todos los compañeros por compartir sus prácticas pedagógicas. [These type of experiences are a springboard, they promote new initiatives. Thanks to the workmates for sharing your pedagogical practices]" (Participant Vidal, M.).

A goal in this category was the interaction between teachers to create opportunities for collaborative works, and even though this was not the most common category in the analysis of the live comments. Some expressions opened the gate towards collaboration and co-creation of strategies, mainly based on the perception of similarities between the presented proposal and the teacher's needs, or in the perception of complementing opportunities for disciplines and careers.

"Felicidades profeee! Misma carrera, diferentes sedes, necesitamos unirnos y pensar en un proyecto juntos.:(-) [Congratulations, teacher! Same career, different places, we need to gather and think of a project together]" (Participant Londoño, A.).

"Profe David ¿Es posible unir esfuerzos con Zipaquirá curso de mercadeo social para ayudarles con estrategias de marketing? [Professor David, Is it possible to gather efforts with Zipaquirá, the course called Social Marketing, to help you think about marketing strategies?]" (Participant Torres, G.). 
The unexpected fact during the meeting was the presence of students, who also acknowledged their teachers' work and showed some perceived impacts students recognize from the utilization of these strategies, in their learning process.

"Como estudiante me siento muy contenta por haber contado con tan excelente profesional, gracias profe Patricia por su dedicación. Gracias a usted la psicología organizacional es una de mis pasiones [As a student I feel very content for having counted with such an excellent professional, thank you, professor Patricia, for your dedication. Thanks to you, Organizational Psychology is one of my passions]" (Student Toro, C.).

\subsubsection{Networking results from the on-line survey}

The online survey had one question related to networking: interaction possibilities, to be evaluated from one to five, being five the highest possible grading, resulting in an average score of 4.29 , which showed a positive perception of the possibility the event provided for teachers to interact with their peers.

The open questions were analyzed using the same categories for the live comments, showing that for the networking category, the essential element was Peer Acknowledgment, followed by the perception of sharing and interaction possibilities and the collaboration opportunities.

This analysis showed that for teachers, one of the critical elements was their perception of interaction because "...tuvimos la oportunidad de escuchar y ser escuchados [we had the opportunity to listen and being listened to]" (Participant 18). As they saw this meeting as "el espacio para compartir las experiencias y aprender de otros para retarse a nuevas posibilidades [the space to share experiences and learn from others to challenge ourselves to new possibilities]" (Participant 34). Being taken into account and being able to learn from their peers from different regions of the country was highly valued by participants, and it is precisely that element that opened the connection to the Democratization of Knowledge category and its relation to the networking possibilities and peer acknowledgment. In the survey, the question related to the perceived quality of pedagogical practices got an average score of 4.39 , however, when checking the open questions it was not clear what they wanted their peer to improve or what they understood for innovative practice.

\subsection{Democratization of Knowledge}

Democratizing knowledge was one of the motives to hold the meeting in an on-line methodology, mainly to giver access to those teachers who, for many different reasons, did not have the opportunity to attend an oral event. As shown in the characterization of the event, 22 branches of the university attended the meeting, along with other institutions and international participants. This result was confirmed with the survey results, specifically in the question related to "regional participation" that got an average score of 4.57 over 5 .

Comments of this category relate to the opportunity teachers had to participate in different cities and places

"Definitivamente mayor cobertura. Si el evento hubiera sido en Bogotá me lo hubiera perdido [Definitely wider coverage, if the event had been in Bogotá I would have missed it]" (Participant 62). 
"Interactuar con la tecnología, y la comunicación, desde diferentes espacios para poder conectarnos todos al mismo tiempo, desde los diferentes lugares en los que UNIMINUTO posee operación [Interactiong with technology and communication from different spaces, to be able to connect at the same time from those many places where UNIMINUTO operates]" (Participant 56, survey).

That lead to other perceived benefits such as flexibility to be in other activities and places like work, while attending the event, thanks to technology "Pude estar en mi trabajo y mirar el evento por medio de mi cellular [I was in my job and watched the event from my cellphone] (Participant 25, survey).

However, the most critical benefits for teachers were, first, the perception of usability of those pedagogical practices presented by their coworkers and peers from different places of the university, in the own practices and towards the university goals, bringing together the Democratization of Knowledge and Networking:

"Lo que más me gustó de las experiencias de las prácticas socializadas es que se pueden realizar y aplicar desde diferentes áreas del conocimiento, en los diferentes programas de formación, articulando no solo los ejercicios y estrategias para el proceso de enseñanza aprendizaje, sino la extensión a la proyección social, y a la investigación [What I liked the most from experiences and socialized practices is that they can be applied from different áreas of knowledge, in different academic programs, articulating not only exercises and strategies for the teachinglearning process, but also social projection and Research]." (Participant 60, survey).

"Me parece muy buena esa innovación debido a que cumple una función importante de la Universidad, la cual es aportar respuestas a los problemas de la sociedad [I consider this innovation to be very good because it fulfills an important function of the university, to give answers to real problems of the society]" (Participant Lamby, J.; live comment).

The second was the reduction in logistic costs for the University and for teachers, such as space rental, transportation, and logistic features like time management, with an average score of 4.61, and transmission quality (made from the University's studio) with an average score of 4.51.

\section{Discussion \& Conclusion}

To ensure the appropriation of educational innovations, many authors pointed at diffusion, networking, and collaboration as the keystones to ensure strong academic processes, sustainable and efficient in time (Ellis, 2017; Kunnari \& Ilomäki, 2016; Ching \& Hursh, 2014; Hrabowski, 2014). Projects like the Engage- In, UNIMINUTO's teachers' network, are being developed to ensure their interaction (Castellanos \& Cipagauta, 2019). Nevertheless, these spaces require others like the meeting innovative pedagogical practices to support them as ignitors.

The analysis performed on the event itself, and the obtained results of the event lead to conclude that this on-line strategy fulfilled and surpassed the initial expectations about the teachers' perceptions of access and coverage, knowledge democratization and networking possibilities, which so far validate the on-line communication strategy for the meeting development. 
Some of the most relevant results obtained in the meeting were beginning with the recognition of colleagues in different places of Colombia, the co-evaluation exercises performed by teachers, and the possibility to establish ways to interact, that not necessarily depended on whether they work in the same physical spaces. The meeting allowed them to identify new interaction ways, to start creating joint proposals and new ways to innovate collectively. At the same time, they could start working interdisciplinary around the same general topic of problem, which in the end would also enhance their students' competencies and open path to educational researches about learning outcomes and its impact in different contexts.

Other unexpected results where the participation of students during the event, who recognized and acknowledged their teacher's practices, opening new research towards the analysis of student's perception of the benefits from those innovative practices; and the participation of other institutions, from other educational levels, from inside and out the country. That scenery gives new possibilities for both the Center and the University, to promote their teachers, stablish new networks and collaboration opportunities towards educational innovation, which could allow expanding the impact and scope of these practices aiming educational improvement in different levels.

\section{Acknowledgment}

This article is a result of the project Educational Innovation, developed by the Center for Teaching Excellence aeiou at UNIMINUTO, based on the participation and work of all those teachers who have attended the Annual Meeting for Innovative Practices, without whom this research could not be possible.

\section{References}

Beames, S. (2017). Innovation and outdoor education. Journal of Outdoor and Environmental Education, 20(1), 2-6.

Blink Learning. (noviembre de 2018). IV estudio sobre el uso de la tecnología en la educación. Obtained from https://www.realinfluencers.es/2018/11/13/iv-estudio-sobre-el-uso-de-latecnologia-en-la-educacion/

Castellanos, V., \& Cipagauta, M. (2019). Engage in: construyendo buenas prácticas docentes en red . XXI Encuentro Internacional Virtual Educa Perú 2019. Obtained from e https://encuentros.virtualeduca.red/storage/ponencias/peru2019/NEzndJDnxdlAyPLMFzz nOdIIPokYSSnmjFayAeP1.pdf

Ching, C., \& Hursh, A. (2014). Peer modeling and innovation adoption among teachers in online

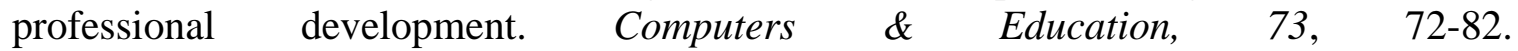
DOI:https://doi.org/10.1016/j.compedu.2013.12.011

Cipagauta, M., \& Bautista, M. A. (septiembre de 2019). Las prácticas pedagógicas un reconocimiento a la innovación. Brazilian Journal of Development. DOI:https://doi.org/10.34117/BJDV5N9-081

Corporación Universitaria MInuto de Dios . (2017). Acerca de UNIMINUTO: Misión, mega y principios. Obtained from http://www.uniminuto.edu/mision-mega-principios 
Ellis, A. (2017). The Nature of Educational Innovation. Otechestvennaya $i$ zarubezhnaya pedagogika, 4(41), 8-22. Obtained from https://cyberleninka.ru/article/n/the-nature-ofeducational-innovation

Hernández- Sampieri, R., Fernández, C., \& Baptista, P. (2014). Metodología de la Investigación (Sexta ed.). México D.F.: McGraw Hill.

Hrabowski, F. (2014). Institutional Change in Higher Education: Innovation and Collaboration. Peabody Journal of Education, 89(3), 291-304. doi:10.1080/0161956X.2014.913440

Huertado, E. (2014). ¿Cuáles son las tendencias en las metodologías de enseñanza de la última década en iberoamérica?1. Revista Científica, (18), 86- 99.

Inefuku, H. (3 de July/ August de 2017). Globalization, Open Access, and the Democratization of Knowledge. Educause Review, 52(4). Obtained from https://er.educause.edu/articles/2017/7/globalization-open-access-and-thedemocratization-of-knowledge

Jakovljevic, M. (2019). Criteria for Empowering Innovation in Higher Education. Africa Education Review, 16(4), 53-71. doi:https://doi.org/10.1080/18146627.2017.1369855

Kovacs, H. (2019). Teacher learning in innovative learning environments in the context of educational reforms and developmental interventions (Doctoral Thesis). Obtained from http://hdl.handle.net/10451/39754

Kunnari, I., \& Ilomäki, I. (2016). Reframing teachers' work for educational innovation. Innovations in Education and Teaching International, 53(2), 167-178. Obtained from http://dx.doi.org/10.1080/14703297.2014.978351

Laudadío, M. J., \& Da Dalt, E. (2014). Estudio de los estilos de enseñanza y estilos de aprendizaje en la Universidad. Educación y Educadores, 17(3), 483- 498.

Lawrence, J., Brown, A., Redmond, P., \& Basson, M. (August 2019). Engaging the disengaged: Exploring the use of course-specific learning analytics and nudging to enhance online student engagement. Student Success, 10(2), 47-58. DOI:10.5204/ssj.v10i2.1295

Liu, H., (December 2018). Innovation on Education and Training Mode of Human Resource Management Specialty in Colleges and Universities from the Perspective of Enterprise Simulation. Educational Sciences: Theory and Practice, 18(6), 3812-3818. DOI:10.12738/estp.2018.6.294

Loera, G., Nakamoto, J., Rueda, R., Oh, J., Beck, C., \& Cherry, C. (2013). Collaboration, Communication, and Connection: Collegial Support and Collective Efficacy among Health Science Teachers. Career and Technical Education Research, 38(3), 191-209. DOI:10.5328/cter38.3.191

Mayolo-Deloisa, K., Ramos-de-la-Peña, A., \& Aguilar, O. (December 2019). Research-based learning as a strategy for the integration of theory and practice and the development of disciplinary competencies in engineering. International Journal on Interactive Design and Manufacturing, 13(4), 1331-1340. DOI: https://doi.org/10.1007/s12008-019-00585-4

Rees, D., Gerber, E., Carlson, S., \& Easterday, M. (May 2019). Opportunities for educational innovations in authentic project-based learning: understanding instructor perceived 
challenges to design for adoption. Educational Technology Research and Development, 67(4). DOI:https://doi.org/10.1007/s11423-019-09673-4

Roberts, D. (Octubre- Diciembre de 2018). Active Learning Precursors in Multidisciplinary Large Lectures: A Longitudinal Trial on the Effect of Imagery in Higher Education Lectures. College Teaching, 66(4), 199- 210.

Taylor, A., Butterwick, S., Raykov, M., Glick, S., Peikazadi, N., \& Mehrabi, S. (31 de October de 2015). Community Service-Learning in Canadian Higher Education. University of Vancouver, Vancouver Canadá. Obtained from https://open.library.ubc.ca/cIRcle/collections/facultyresearchandpublications/52383/items $/ 1.0226035$

Unión Europea. (2017). Marco Europeo para la competencia digital del profesorado (DigCompEdu). Obtained from https://ec.europa.eu/jrc/sites/jrcsh/files/digcompedu_leaflet_es-nov2017pdf.pdf

Warford, M. (2017). Educational Innovation Diffusion: Confronting Complexities. En A. Sidorkin, \& M. Warford (Edits.), Science, Technology and Innovation Studies. Reforms and Innovations in Education (págs. 11-36). Moscow: Springer. DOI:10.1007/978-3-31960246-2

Watty, K., McKay, J., \& Ngo, L. (September 2016). Innovators or inhibitors? Accounting faculty resistance to new educational technologies in higher education. Journal of Accounting Education, 36, 1-15. DOI:https://doi.org/10.1016/j.jaccedu.2016.03.003 